\title{
Diphyllobothrium latum (Cestoda: Diphyllobothriidea) in perch (Perca fluviatilis) in three sub-alpine lakes: influence of biotic and abiotic factors on prevalence
}

\author{
Barbara WICHT ${ }^{1,2)}$, Costanzo LIMONI ${ }^{3)}$, Raffaele PEDUZZI ${ }^{2)}$ and Orlando PETRINI ${ }^{1)}$ \\ ${ }^{1)}$ Istituto Cantonale di Microbiologia, Bellinzona, Switzerland \\ ${ }^{2)}$ Faculté des Sciences, Département de Botanique et Biologie Végétale, Laboratoire d'Ecologie Microbienne, Université de Genève, \\ Geneva, Switzerland \\ ${ }^{3)}$ Alpha5, Biometrics \& Data Management, Riva San Vitale, Switzerland \\ *e-mail corresponding author: barbarawicht@yahoo.it
}

\begin{abstract}
In recent years, human diphyllobothriosis has staged a comeback in Swiss, French and Italian sub-alpine regions. The main putative infective source of the causative agent (the tapeworm Diphyllobothrium latum) in these areas is perch (Perca fluviatilis). Therefore, the occurrence of D. latum in this fish species was investigated between 2005 and 2008 in the sub-alpine lakes Maggiore, Lugano and Geneva. Prevalence in fish of Lake Maggiore was $14 \%(n=880)$. In Lake Geneva, 5.1\% fillets $(n=532)$ were infected, whereas perch from Lake Lugano were free from the parasite. These results are discussed in relation to previous studies. Data on fish size and weight indicate that infection of perch by D. latum is independent of age and sex. Abiotic factors considered critical for D. latum life cycle (water temperature and oxygen concentration) characterize the three basins and were related to their infestation frequencies. The presence of this parasite was most likely favoured by warmer, well oxygenated waters. Previous studies indicate that the lake's trophic state (i.e. content of total phosphorus) influenced the availability of the first intermediate hosts (copepods) of some pseudophyllideans. In our study, no correlation was observed between the amount of phosphorus and the number of copepods in populations of zooplankton. Nevertheless, the trophic states of the three lakes seemed to affect the degree of infection in fish. In conclusion, at least in sub-alpine lakes, abiotic factors such as water temperature, oxygenation and trophic state seem to have an influence on maintaining or preventing perch infection with $\mathrm{D}$. latum.
\end{abstract}

Key words: food-borne zoonoses, emerging infections, flatworms, helminths

\section{INTRODUCTION}

Human diphyllobothriosis is a cosmopolitan fishborne zoonosis caused by tapeworms of the genus Diphyllobothrium (Cestoda: Diphyllobothriidea). The life cycle of the causative agent includes two intermediate hosts (copepods and fish) and a definitive host (a fish-eating mammal, mainly man). In the last 20 years, this disease has experienced an unexpected comeback in Swiss, French and Italian sub-alpine regions (DupouyCamet \& Peduzzi 2004; Peduzzi 1990). Epidemiological monitoring and molecular identification of clinical cases in this area have revealed the presence of D. latum (the main autochthonous species infecting humans), as well as D. nihonkaiense and D. dendriticum (allochtonous species; Yéra et al. 2006; Wicht et al. 2007; Wicht et al. 2008; Paugam et al., in press). Perch (Perca fluviatilis) was identified as a frequent host of plerocercoid larvae of $D$. latum. In the past years, a high prevalence in this fish has been demonstrated in several subalpine lakes: up to $33 \%$ of the population investigated was infected in Lake Orta (Northern Italy; Peduzzi \& Boucher-Rodoni 2001); from $3.7 \%$ to $14.2 \%$ in the lakes of Bienne and Morat (Swiss Plateau; Golay \& Mariaux 1995); 4-10\% in Lake Geneva (Nicoulaud et al. 2005); $7.8 \%$ in Lake Maggiore and $30 \%$ on average in Lake Como (Bonini et al. 1998; Gustinelli et al. 2007). However, some basins located in this region, such as lakes Varese and Lugano, were free from the parasite (Dupouy-Camet \& Peduzzi 2004).

The presence of definitive hosts releasing eggs in water is obviously among the major requirements for maintaining Diphyllobothrium in a water system. This condition being satisfied in endemic sub-alpine areas, environmental factors might play a role in the development of ontogenetic stages of this tapeworm. Abiotic parameters such as water temperature, oxygen concentration (because eggs are aerobic) and light affect Diphyllobothrium embryonic development and the hatching of eggs (von Bonsdorff 1977). Moreover, for some freshwater fish parasites that depend on zooplankton for their development, the availability of these hosts has been linked to the lake's trophic state (determined by total phosphorus). Thus, oligotrophic conditions may lead to an increased ratio of copepods to cladocerans (Molzen 2005). On the contrary, eutrophic conditions would increase the proportion of cladocerans in zooplankton, reducing the availability of copepods as first intermediate hosts and therefore impairing the parasitic life cycle. The trophic state could therefore 
represent another crucial component for the maintenance of Diphyllobothrium in a water body. To our knowledge, no previous studies that include these variables have been conducted on the occurrence of Diphyllobothrium in sub-alpine lakes.

The main objective of this study was to survey the occurrence of diphyllobothriosis in perch of the lakes Maggiore, Lugano and Geneva from 2005 to 2008. Fish samples were checked for the presence or absence of plerocercoid larvae, the identity of which was confirmed with molecular methods. Biotic (weight, size and sex of the fish) and abiotic factors affecting embryonation and egg hatching (water temperature and dissolved oxygen), were also taken into account. Trophic states of these lakes, evaluated by rates of total phosphorus in the epilimnion, were correlated with the occurrence of the parasite and the presence of its first intermediate hosts.

\section{METHODS}

\subsection{Sampling}

The study was carried out from July 2005 to June 2008. Samples of perch (Perca fluviatilis) were collected usually once in each season.

In Lake Maggiore, at least 200 individuals were collected each year. Fish were caught using gill nets with $28 \times 28 \mathrm{~mm}$ mesh. Due to unfavorable weather conditions, sampling in winter 2007 could not be performed. Fifteen stations [Brissago, Porto Ronco, Ascona, Locarno, Muralto, Tenero, Foce Verzasca, Magadino, Vira Gambarogno, San Nazzaro, Gerra Gambarogno and Ranzo (Swiss part), Cannero, Baveno and Monvalle (Italian part)] were chosen to obtain a representative sample for the whole lake.

In Lake Geneva, a regular monitoring was carried out only from June 2006 to January 2008, as previous data were taken from Nicoulaud et al. (2005). Samples consisted mainly of perch fillets provided by local fishermen. Six stations were chosen in Petit Lac (Mies and Versoix, Canton Geneva, Switzerland) and in Grand Lac (Morges and Paudex in Canton Vaud, Switzerland; Séchex and Thonon-les-Bains in department of HauteSavoie, France), which are characterized by different depths and intervals of water mixing, leading to different concentrations of oxygen and phosphorus (Lazzarotto et al. 2006).

Lake Lugano was sampled once in October 2005 and once in January 2006, and seasonally thereafter using gill nets with $32 \times 32 \mathrm{~mm}$ mesh. Eight stations [Figino, Agno, Morcote, Brusino Arsizio and Capolago (South basin), Bissone and Gandria (North basin), and Ponte Tresa] were chosen in three compartments with different hydrological characteristics in Switzerland.

\subsection{Fish analysis and parasite identification}

Either whole fishes or fish fillets were investigated, depending on the type of samples provided by the fish- ermen. Size (total length, measured from the extremity of the head until the inferior lobe of the tail) and sex were recorded for each fish. Both whole individuals and fillets were weighted.

Plerocercoids were isolated by visual inspection and successively identified by molecular methods. DNA was extracted from each larva following the Tissue Protocol of the QIAamp DNA Minikit (QIAGEN, Hombrechtikon, Switzerland). About $50 \mathrm{ng} \mu \mathrm{L}^{-1}$ DNA were tested by polymerase chain reaction using the Taq PCR Master Mix Kit (QIAGEN, Hombrechtikon, Switzerland), with specific primers for cytochrome c oxidase subunit I (Cox-1) complete gene amplification (Nakao et al. 2007). This mitochondrial gene is considered as the most discriminant within Diphyllobothrium (Isobe et al. 1998; Yéra et al. 2008). Amplicons were directly purified with NucleoSpin ${ }^{\circledR}$ Extract II Kit (MachereyNagel, Oensingen) and DNA was quantified with a ND100 Spectrophotometer (NanoDrop Technologies Inc., Wilmington, USA). Sequencing reaction was prepared using the ABI PRISM ${ }^{\circledR}$ BigDyeTM Terminator v1.1 Cycle Sequencing Kit (Applied Biosystems, Rotkreuz, Switzerland). After purification by filtration through MFTM membrane filters $0.025 \mu \mathrm{m}$ (Millipore, Zug, Switzerland), samples were loaded in an automatic sequencer (ABI PRISM ${ }^{\circledR} 310$ Genetic Analyzer, Perkin Elmer, Rodgau-Jügesheim, Switzerland). Manually corrected sequences were aligned in a Neighbor-Joining tree (Kimura-2 parameters; bootstrap values for 1,000 replicates; MEGA version 3.0; Kumar et al. 2004) and analysed by a BLAST search (Altschul et al. 1990).

\subsection{Statistical analyses}

The prevalence of Diphyllobothrium in the samples was calculated for each lake. The age of the fishes was estimated from their weight and size according to Negri (2000) and Muus et al. (1971).

Missing weights of either fish or fillets were estimated using the formula:

$$
\text { Fillet weight }=1.915+0.213 \times \text { Fish weight }
$$

derived from a regression analysis performed on the samples for which both fillets and whole fish weights were available $\left(r^{2}=0.95\right)$.

The correlation between prevalence of infection and estimated weight, size, and sex of fish were checked graphically and using a chi square test. Perch show different linear and weight growth curves depending on their sex (Negri 2000). Correlation between fish weight and infection and between fish size and infection was therefore computed separately for female and male.

Monthly patterns of temperature, oxygen concentration and total phosphorus in the epilimnion $(0-20 \mathrm{~m}$ depth), measured from January 2005 to December 2007 in all lakes (C.N.R.-I.S.E. 2008; CIPEL 2008; UPDA 2008), were analyzed graphically using scatterplot matrices. 


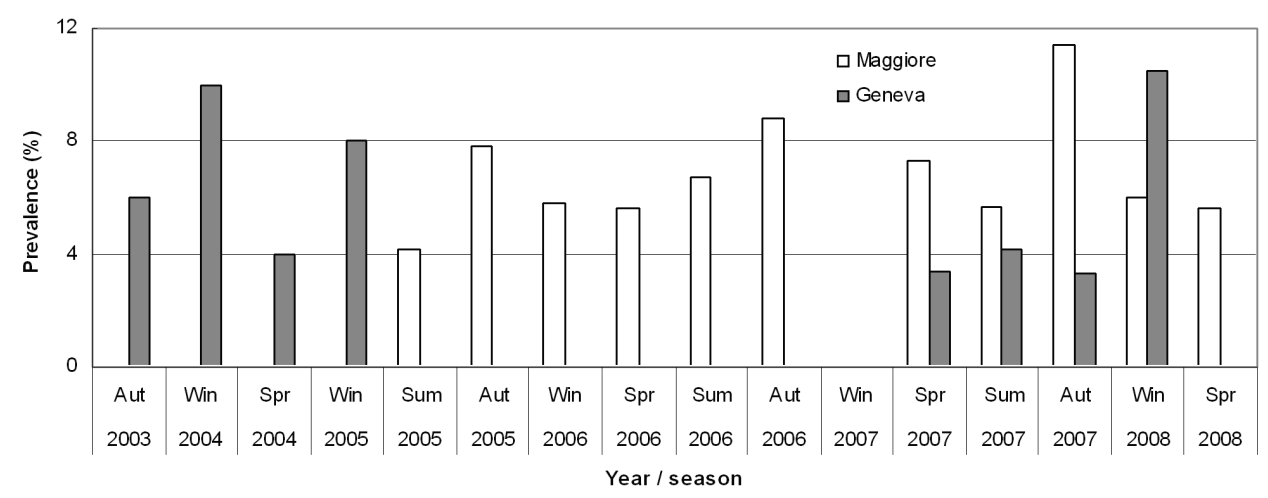

Fig. 1. Seasonal prevalence (\%) of D. latum in perch fillets, sampled in Lake Maggiore and Lake Geneva from autumn 2003 to spring 2008 (data for 2003-2005 from Nicoulaud et al. 2005). Win: winter; Spr: spring; Sum: summer; Aut: autumn.

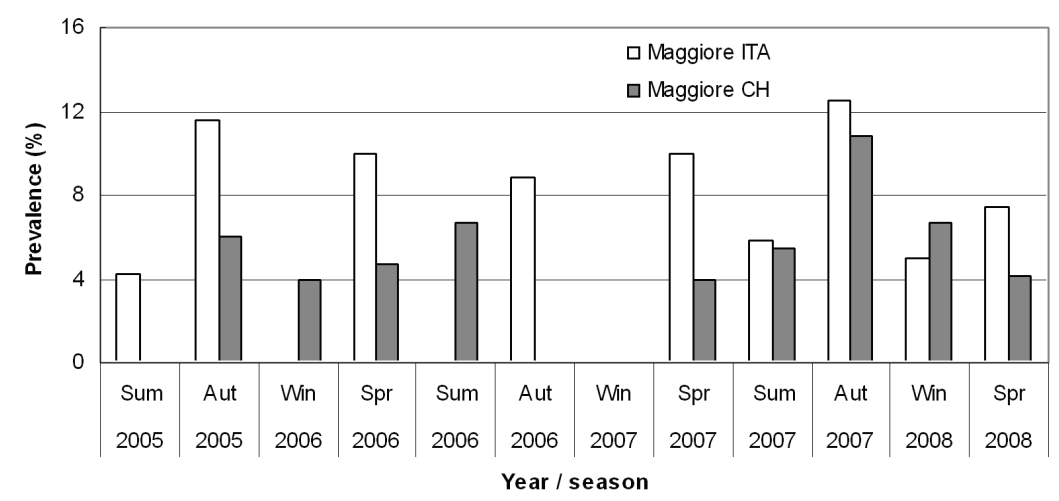

Fig. 2. Seasonal prevalence (\%) of $D$. latum in perch fillets sampled in the Italian and in the Swiss portion of Lake Maggiore from summer 2005 to spring 2008. Win: winter; Spr: spring; Sum: summer; Aut: autumn.

For the same period, the correlation between the trophic state and the availability of copepods was checked for each water system. About 40 cylopoid and calanoid species can be infected by Diphyllobothrium (Scholz et al. 2009). It has been suggested that their infection occurs mainly in littoral waters, where light and temperature conditions are more favourable to the development of coracidia (von Bonsdorff 1977). Most of the species present in the studied lakes (Mixodiaptomus laciniatus, Eudiaptomus padanus, Cyclops abyssorum, Megacyclops viridis and Mesocyclops leuckarti in Lake Maggiore; Eudiaptomus gracilis, Cyclops vicinus, Cyclops prealpinus and Macrocyclops albidus in Lake Geneva; Eudiaptomus gracilis, Cyclops abyssorum, Thermocyclops crassus and Mesocyclops leuckarti in Lake Lugano) have been shown to be involved in the $D$. latum life cycle. As the parasite shows a quite broad specificity for its first intermediate hosts, we chose to pool them for the statistical analysis. The total phosphorus in the epilimnion $(0-20 \mathrm{~m})$ and the ratio of copepods to cladocerans (number of individuals per $\mathrm{m}^{3}$ sampled from 0-50 m; C.N.R.-I.S.E., 2008; CIPEL 2008; UPDA 2008) were compared by Analysis of variance (ANOVA).

All statistical calculations were carried out with SPSS version 14.0 (SPSS Inc. 2006).

\section{RESULTS}

\subsection{Parasite identification}

Molecular analysis of 94 parasites confirmed $100 \%$ identity of $1566 \mathrm{bp}$ long sequences of the Cox-1 gene with D. latum (GenBank accession number AM778554: plerocercoid from perch of Lake Como, Italy and DQ985706: adult worm from a Russian patient). The similarity with a D. latum adult worm from another Russian patient (AB269325) was 99.9\%.

The intraspecific variation consisted in a nucleotide substitution at position 90, where an adenine (A) replaced a guanine $(\mathrm{G})$ in the sequence $\mathrm{AB} 269325$; this substitution is silent, because it does not affect the codon translation.

\subsection{Prevalence}

Plerocercoids of $D$. latum were detected in $14 \%$ of the perch population studied $(\mathrm{n}=880)$ in Lake Maggiore, the highest prevalence being recorded in autumn, and $5.1 \%$ fillets $(\mathrm{n}=532)$ in Lake Geneva, the highest prevalence being in winter (Fig. 1). Perch caught in the Italian part of Lake Maggiore were more infected than those sampled in the Swiss part $(16.3 \%$ and $12 \%$; Fig. 2). In Lake Geneva, the prevalence was 


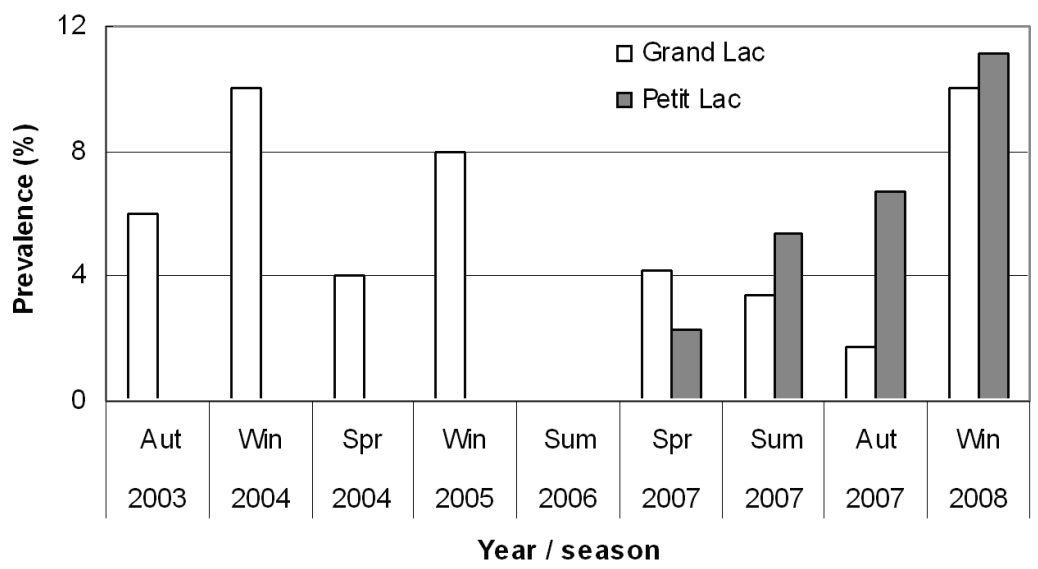

Fig. 3. Seasonal prevalence (\%) of D. latum in perch fillets, sampled in Petit Lac and Grand Lac (Lake Geneva) from autumn 2003 to winter 2008 (data for 2003-2005 from Nicoulaud et al. 2005). Win: winter; Spr: spring; Sum: summer; Aut: autumn.

higher in Petit Lac (6.4\% of the fillets) than in Grand Lac (4.5\%, Fig. 3). No plerocercoid larvae were seen in 208 perch sampled in Lake Lugano.

With few exceptions, each fish/fillet was infected by only one plerocercoid. Infection by two plerocercoids was seen in 3 individuals from Lake Maggiore (Porto Ronco and San Nazzaro in spring 2007, and Monvalle in March 2008).

\subsection{Biotic factors}

In Lake Maggiore, the prevalence was $5.2 \%$ in males $(\mathrm{n}=328)$ and $4.8 \%$ in females $(\mathrm{n}=800)$. The presence of plerocercoids of $D$. latum was not related with the sex of the fish $(n=1128$, Chi-Square $=0.094, p$ $=0.762$ ). No correlation was seen between infection and the weight or size of fish, regardless of sex (data not shown).

In Lake Geneva no correlation was found between infection by $D$. latum and weight of the fillets $(\mathrm{n}=461)$.

\subsection{Abiotic factors}

Respective monthly values of temperature $\left({ }^{\circ} \mathrm{C}\right)$, dissolved oxygen $\left(\mathrm{mg} \mathrm{L}^{-1}\right)$ and total phosphorus $\left(\mu \mathrm{g} \mathrm{L}^{-1}\right)$ in the epilimnion characterized each lake (Fig. 4; Tab. 1). Lake Maggiore showed a profile with low rates of total phosphorus (oligotrophy), the highest temperatures and high rates of dissolved oxygen. Lake Geneva (both Grand and Petit Lac) showed a similar profile of oxygen and temperatures, with moderately higher values of phosphorus (mesotrophy). Lake Lugano was characterized by high concentration of total phosphorus (eutrophy), lower temperatures and lower dissolved oxygen, showing a markedly different pattern compared to the two other basins.

No significant correlations were seen between the content of phosphorus and the availability of the first intermediate hosts. The amount of total phosphorus in the epilimnion had no influence on the number of copepods (linear regression analysis: Lake Maggiore: $p=$
0.771; Lake Geneva: $p=0.788$; Lake Lugano: $p=0.48$ ). No correlation was found between total phosphorus and ratio of copepods to cladocerans in lakes Maggiore (Pearson's correlation $=0.316, p=0.073$ ) and Geneva (Pearson's correlation $=-0.253, p=0.178$ ); a positive correlation was seen only in Lake Lugano (Pearson's correlation $=0.414, p=0.012$ ).

\section{DISCUSSION AND CONCLUSIONS}

\subsection{Prevalence}

Between 2005 and 2008, D. latum plerocercoids were detected in perch in lakes Maggiore and Geneva. Fish in Lake Lugano was free from the parasite, confirming the results of previous studies (Dupouy-Camet \& Peduzzi 2004).

The average prevalence in perch of Lake Maggiore (14\%) has increased, especially if compared with previous surveys (7.8\% in 1996; Bonini et al. 1998). The prevalence in fillets of Lake Geneva decreased slightly during the last 5 years: from $7 \%$ in 2003-2005 (Nicoulaud et al. 2005) to $5.1 \%$ in $2006-2008$. However, the difference in sampling sites between the two periods (only Thonon-les-Bains in the previous survey, whereas 6 stations in this survey) did not allow us to draw any firm conclusion. In both lakes, the highest prevalence of infection was detected during the cold seasons (autumn and winter).

\subsection{Biotic factors}

The absence of correlation between the presence of the parasite and both linear and weight growth curves of perch of both sexes indicated that infection by $D$. latum of fish collected in Lake Maggiore occurred most likely throughout the whole fish life. The lack of any correlation between fillet weight and infection in Lake Geneva, even if the sex of fish could not be considered, led to the same conclusion. Estimated ages of infected samples from Lake Maggiore ranged from about $3(16 \mathrm{~cm}$ length; $43.4 \mathrm{~g}$; male caught in summer 2007) to more than 10 years $(39 \mathrm{~cm} ; 850.3 \mathrm{~g}$; female caught in winter 


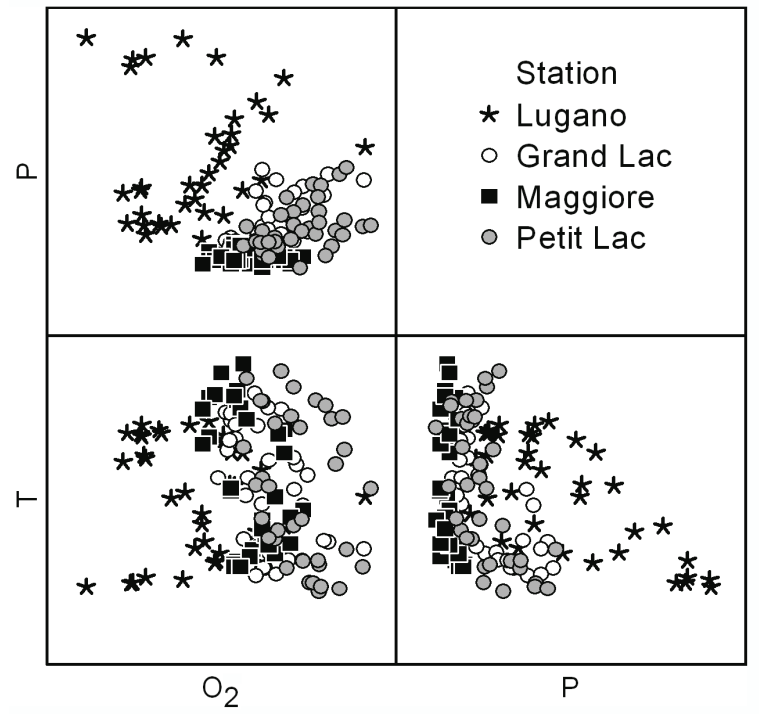

Fig. 4. Scatterplot matrix based on monthly values of temperature $\left({ }^{\circ} \mathrm{C}\right)$, dissolved oxygen $\left(\mathrm{mg} \mathrm{L}^{-1}\right)$ and total phosphorus $\left(\mu \mathrm{g} \mathrm{L}^{-1}\right)$ in the epilimnion (0-20 m) for the years 2005, 2006 and 2007, in lakes Lugano, Geneva (Petit Lac and Grand Lac) and Maggiore.

Tab. 1. Average seasonal temperatures $\left({ }^{\circ} \mathrm{C}\right)$ in lakes Maggiore, Geneva and Lugano, from 2005 to 2007. Win: winter; Spr: spring; Sum: summer; Aut: autumn.

\begin{tabular}{lcccccccccccc}
\hline LAKE & Win '05 & Spr '05 & Sum '05 & Aut '05 & Win '06 & Spr '06 & Sum '06 & Aut '06 & Win '07 & Spr '07 & Sum'07 & Aut '07 \\
\hline L. Maggiore & 6.9 & 11.6 & 18.6 & 13.4 & 7 & 10.5 & 17.5 & 13.2 & 8.1 & 13.8 & 18.7 & 9.2 \\
L. Geneva & 6 & 10.1 & 17.3 & 10.9 & 5.5 & 10.7 & 16.4 & 12.9 & 6.8 & 12.7 & 17.1 & 11.7 \\
L. Lugano & 5.8 & 11.9 & 15.8 & 10.9 & 5.2 & 11.7 & 15.6 & 11.4 & 7 & 12.7 & 15.5 & 10.5 \\
\hline
\end{tabular}

2006-2007). Estimated ages of infected samples from Lake Geneva ranged from about $2(21.3 \mathrm{~g})$ to $5-10$ years (199.5 g; both fish caught in winter 2007-2008). This demonstrates that the D. latum life cycle was ongoing in these basins, at least until 2004 in Lake Maggiore, and until 2006 in Lake Geneva.

No difference in D. latum prevalence was found between male and female.

\subsection{Abiotic factors}

Statistical analysis of temperature, dissolved oxygen and concentration of total phosphorus in the epilimnion indicated a correlation between the presence of Diphyllobothrium and the lake's profile. Lake Maggiore, where the average prevalence of $D$. latum was the highest ( $14 \%$ fish, i.e. $7 \%$ fillets) was characterized by warmer, well oxygenated water and oligotrophic conditions. Lake Geneva (5.1\% fillets infected) was characterized by generally lower temperatures but higher oxygen concentration, and by mesotrophic conditions. As perch is a sedentary species (Muus et al. 1971), these data support the hypothesis that warm temperatures and high oxygen concentrations probably improve the conditions for the establishment of a parasitic life cycle. The abiotic profile of Lake Lugano (where D. latum was absent) was markedly different from that of the infected lakes, and was characterized by the lowest temperatures, the lowest dissolved oxygen and water eutrophy. For all lakes, the presence of the first intermediate hosts was not correlated with phosphorus concentration.

Between 2002 and 2007, more than 260 human cases were reported on the Swiss and French shores of Lake Geneva while, from 2001, 40 cases were documented in the Insubrian region (lakes Maggiore, Lugano and Como; Wicht et al. unpublished). Such difference in the prevalence of human cases seems nevertheless to be unrelated to the variability of prevalence in local perch. These considerations suggest that the occurrence of $D$. latum in a lake is not only dependent on the presence of definitive hosts releasing eggs in water, and that abiotic factors could play a major role in maintaining (or in preventing) fish infection. For instance, Lake Lugano is located in an endemic area, but its perch are free from diphyllobothriosis.

Seasonality seems to be another parameter affecting infection frequencies. Under favorable environmental conditions (oxygen concentration: $8-12 \mathrm{mg} \mathrm{L}^{-1}$ ), transmission of Diphyllobothrium parasites to fish takes place quite rapidly (von Bonsdorff 1977). At $16-20^{\circ} \mathrm{C}$, eggs hatching takes 8-12 days; the development of procercoid larvae in copepods another 2-6 weeks (Bylund 2003). These data support the hypothesis that the best period for the transmission of D. latum to perch in lakes Maggiore and Geneva is summer. In fact, average oxygen concentrations in August from 2005 to 2007 were $9.2 \mathrm{mg} \mathrm{L}^{-1}$ in Lake Maggiore and $10.3 \mathrm{mg} \mathrm{L}^{-1}$ in Lake 
Geneva (6.6 $\mathrm{mg} \mathrm{L}^{-1}$ in Lake Lugano; data not shown). Average temperatures in the same period were $19.3{ }^{\circ} \mathrm{C}$ in Lake Maggiore and $17.2^{\circ} \mathrm{C}$ in Lake Geneva, but only $15.6{ }^{\circ} \mathrm{C}$ in Lake Lugano (data not shown). In addition, although adult perch (older than 3 years) are commonly considered ichthyophagous, it has been demonstrated that, in some Swiss and Italian lakes, individuals of any age feed on zooplankton during the summer (Brinker 2000; Negri 2000). Adults may switch to consumption of copepods mainly in July, when zooplankton is more abundant and its predation requires a minor energetic effort, compared to fish predation (Negri 2000). This would increase the possibility of a fish being infected by D. latum in the warm season. Moreover, in the last decades bleaks (Alburnus spp.), the main preys of perch in sub-alpine lakes, showed a marked decline, forcing perch to feed on alternative organisms (Peduzzi \& Grimaldi 2007).

\subsection{Limitations of the study}

This study had some limitations. We tried to follow the same methods adopted in previous surveys in the same lakes, but some of the comparisons had to rely on data from previous studies, instead of novel controls. In addition, the monitoring in the individual lakes was not homogeneous. In lakes Maggiore and Lugano we employed the techniques described by Bonini et al. (1998) with regards to sample size, catch of whole individuals, filleting and visual inspection. In Lake Geneva fillets were provided directly by fishermen, as described by Nicoulaud et al. (2005), but with significant differences from the work described by these authors concerning sample size, sampling seasonality and number of stations. In addition, for logistic reasons, sampling could not be carried out consistently in the same periods in different years. The sometimes reduced sample size and missing data did not allow us to perform any confirmatory analyses.

\subsection{Perspectives}

D. latum is considered an indicator of faecal water pollution (von Bonsdorff 1977). In the future, it would be interesting to investigate the presence of infected fish near sewage treatment plants. In our study, the prevalence in the Italian part of Lake Maggiore was higher (16.3\% perch infected) than in the Swiss part $(12 \%)$. Data on the state of the lake indicate that in $200380 \%$ of the population not connected to sewage treatment plants was in Italy, $63 \%$ of which in Lombardy and 37\% in Piedmont; conversely, more than $90 \%$ of the population was connected in Switzerland (CIPAIS, 2003). Nevertheless, the situation in Italy has markedly improved in the last years and the quality of waters has now greatly improved (CIPAIS 2003).

It is possible that climatic changes could favour $D$. latum life cycle by warming freshwater systems, thus increasing the percentage of infected fish (Patz et al.
2000; Marcogliese 2001; Sagua et al. 2001). This should also be investigated by future regular monitoring of endemic lakes located in endemic areas.

Other abiotic parameters are known to play a role on the occurrence of $D$. latum in water systems, such as salinity, $\mathrm{pH}$, light intensity and pollutants (von Bonsdorff 1977). Their influence in the sub-alpine lakes deserves to be elucidated as well, and could help explain the differences in fish prevalence.

From a public health perspective, the presence of $D$. latum in perch in the studied lakes is of great importance, as the increasing popularity of raw fish dishes is thought to be linked to the re-emergence of human diphyllobothriosis in the sub-alpine area (Scholz et al. 2009). Health authorities should thus publish consistent and binding guidelines on the proper handling of raw fish as food source.

\section{ACKNOWLEDGMENTS}

We are grateful to all individuals who provided samples, in particular to Walter Branca, Ivano Conti, Armando Polli, Ermanno Gandolfi, Cooperativa Pescatori Professionali del Lago Maggiore, and to Daniel Gerdeaux. The collaboration by Eric Bernardi, Mauro Bordoni, Laurence Calame-Haller, Manuel Marcu, Bruno Polli, Nicoletta Riccardi, Nadia Ruggeri, Jean Pascal Ubertini and Pietro Volta was crucial for the organization of the samplings. We gratefully acknowledge the invaluable help by Minoru Nakao and Tetsuya Yanagida (Department of Parasitology, Asahikawa Medical College, Hokkaido, Japan) in sequencing parts of the genome of the samples. Dr. Gary J. Samuels (USDA/ARS, Beltsville, MD, USA) critically read the manuscript and made helpful comments.

\section{REFERENCES}

Altschul, S.F., W. Gish, W. Miller, E.W. Myers. \& D.J. Lipman. 1990. Basic local alignment search tool. J. Mol. Biol., 215: 403-410.

Bonini, P., S. Montorfani, R. Peduzzi \& P. Renon. 1998. Situazione della plerocercosi nei laghi insubrici italo-svizzeri. Ob. Doc. Vet., 4: 65-71.

Brinker, A. 2000. Der Befall des Flussbarsches (Perca fluviatilis L.) im Bodensee mit dem Hechtbandwurm (Triaenophorus nodulosus $P$.). Diploma thesis. Fakultät für Biologie der Albert-Ludwigs-Universität, Freiburg, Germany: $102 \mathrm{pp}$.

Bylund, B. G. 2003. 17. Diphyllobothrium latum. In: Akuffo, H., E. Linder, I. Ljungström, M. Wahlgren. Parasites of the colder climates. Taylor \& Francis, London. UK: 359 pp.

CIPAIS. 2003. Rapporto sullo stato attuale e fabbisogni di opere per la protezione delle acque italo svizzere. Commissione Internazionale per la protezione delle acque italo-svizzere: $42 \mathrm{pp}$.

CIPEL. 2008. Base de données INRA de Thonon-les-Bains. Données CIPEL - INRA 2005, 2006, 2007. Commission Internationale pour la protection des eaux du lac Léman: (unpublished).

C.N.R.-I.S.E. 2008. Ricerche sull'evoluzione del Lago Maggiore. Aspetti limnologici. Programma quinquennale 20032007. Campagne 2005, 2006, 2007. Commissione Interna- 
zionale per la protezione delle acque italo-svizzere, Verbania, Italy: (unpublished).

Dick, T. A., P. A. Nelson \& A. Choudhury. 2001. Diphyllobothriasis: update on human cases, foci, patterns and sources of human infections and future considerations. Southeast Asian J. Trop. Med. Public Health, 32: 59-76.

Dupouy-Camet, J. \& R. Peduzzi. 2004. Current situation of human diphyllobothriasis in Europe. Euro Surveill., 9: 31-35.

Golay, M. \& J. Mariaux. 1995. Situation de Diphyllobothrium latum, L., 1758, dans quatre lacs du plateau suisse. Bull. Soc. Neuch. Sci. Nat., 118: 79-86.

Gustinelli, A., S. Invernizzi, R. Kuchta \& M.L. Fioravanti. 2007. Fish-borne parasitic zoonoses: recrudescence of diphyllobothriasis in Como lake, Northern Italy. In: International Symposium of Fish Parasites. Viterbo, Italy. Parassitologia, 49 (Suppl. 2) : 202.

Isobe, A., K. Shiwaku, T. Fukushima, T. Gao, D. Gibson, R. Bray, L. Margolis \& Y. Yamane. 1998. Molecular phylogeny of Diphyllobothrium nihonkaiense (Yamane et al., 1986) and other diphyllobothriid tapeworms based on mitochondrial cytochrome $\mathrm{c}$ oxidase subunit I gene sequence. Parasitol. Int., 47: 138.

Kumar, S., K. Tamura \& M. Nei. 2004. MEGA3: Integrated software for molecular evolutionary genetics analysis and sequence alignment. Brief. Bioinform., 5: 150-163.

Lazzarotto, J., P. Nirel \& F. Rapin. 2006. Évolution physicochimique des eaux du Léman - Physical-chemical changes in the waters of Lake Geneva. Campagne 2005. Commission Internationale pour la protection des eaux du lac Léman: 31-63.

Marcogliese, D. J. 2001. Implications of climate change for parasitism of animals in the aquatic environment. Can. $J$. Zool., 79: 1331-1352.

Molzen, B. 2005. Die Auswirkung des Befalls mit Plerocercoiden des Hechtbandwurms (Triaenophorus nodulosus (P).) auf den Flussbarsch (Perca fluviatilis L.) im Bodensee-Obersee. PhD thesis. Ludwig-Maximilians-Universität, Institut für Zoologie, Fischereibiologie und Fischkrankenheiten, München, Germany: $113 \mathrm{pp}$.

Muus, B.J., P. Dahlstrom \& A. Wheeler. 1971. Collins Guide to the Freshwater Fishes of Britain and Europe. Collins, London, UK: $224 \mathrm{pp}$.

Nakao, M., D. Abmed, H. Yamasaki \& A. Ito. 2007. Mitochondrial genomes of the human broad tapeworms Diphyllobothrium latum and Diphyllobothrium nihonkaiense (Cestoda: Diphyllobothriidae). Parasitol. Res., 101: 233-236.

Negri, A. 2000. La biologia del persico reale del Lario. Regione Lombardia, Amministrazione Provinciale di Como, Como, Italy: 140 pp.

Nicoulaud, J., H. Yéra \& J. Dupouy-Camet. 2005. Prévalence de l'infestation par Diphyllobothrium latum, L., $1758 \mathrm{chez}$

Received: September 2008

Accepted: January 2009 les perches (Perca fluviatilis) du lac Léman. Parasite, 12: 362-364.

Patz, J.A., T.K. Graczyk, N. Geller \& A.Y. Vittor. 2000. Effects of environmental change on emerging parasitic diseases. Int. J. Parasitol., 30: 1395-1405.

Paugam, A., H. Yéra, P. Poirier, A. Lebuisson \& J. DupouyCamet. (2008). Bothriocéphalose à Diphyllobothrium nihonkaiense: un nouveau risque lié à la consommation de saumon. Presse Méd.: (in press).

Peduzzi, R. 1990. Résurgence de la bothriocéphalose (parasitose à Diphyllobothrium latum) dans la région du Lac Majeur. Méd. Mal. Infect., 20: 493-497.

Peduzzi, R. \& R. Boucher-Rodoni. 2001. Resurgence of human bothriocephalosis (Diphyllobothrium latum) in the subalpine lake region. J. Limnol., 60: 41-44.

Peduzzi, R. \& E. Grimaldi. 2007. Il problema della melanizzazione nella micosi branchiale da Branchiomyces a carico dell'alborella, Alburnus alburnus alborella (Osteichthyes, Cyprinidae). Biologi Italiani, 2: 5-17.

Sagua, H., I. Neira, J. Araya \& J. González. 2001. Nuevos casos de infección humana por Diphyllobothrium pacificum (Nybelin, 1931) Margolis, 1956 en Chile y su probable relación con el fenómeno de El Niño, 1975-2000. Bol. Chil. Parasitol., 56: 22-25.

Scholz, T., H.H. Garcia, R. Kuchta \& B. Wicht. 2009. Update on the human broad tapeworm (genus Diphyllobothrium), including clinical relevance. Clin. Microbiol. Rev., 22: $146-160$

UPDA. 2008. Ricerche sull'evoluzione del Lago di Lugano. Aspetti limnologici. Programma quinquennale 2003-2007. Campagne 2005, 2006, 2007. Commissione Internazionale per la protezione delle acque italo-svizzere.

von Bonsdorff, B. 1977. Diphyllobothriasis in man. Academic Press, New York, USA: 189 pp.

Wicht, B., F. de Marval \& R. Peduzzi. 2007. Diphyllobothrium nihonkaiense (Yamane et al., 1986) in Switzerland: First molecular evidence and case reports. Parasitol. Int., 56: 195-199.

Wicht, B., F. de Marval, B. Gottstein \& R. Peduzzi. 2008. Imported diphyllobothriasis in Switzerland: molecular evidence of Diphyllobothrium dendriticum (Nitsch, 1824). Parasitol. Res., 102: 201-204.

Yéra, H., C. Estran, P. Delaunay, M. Gari-Toussaint, J. Dupouy-Camet \& P. Marty. 2006. Putative Diphyllobothrium nihonkaiense acquired from a Pacific salmon (Oncorhynchus keta) eaten in France: genomic identification and case report. Parasitol. Int., 55: 45-49.

Yéra, H., J. Nicoulaud \& J. Dupouy-Camet. 2008. Use of nuclear and mitochondrial DNA PCR and sequencing for molecular identification of Diphyllobothrium isolates potentially infective for humans. Parasite, 15: 402-407. 